\title{
Block Teaching as the Basis for an Innovative Redesign of the PG Suite of Programmes in University of Bedfordshire Business School
}

\author{
Kofinas, Alexander; Bentley, Yongmei; Minett-Smith, Cathy and Cao, Guangming \\ Business School, University of Bedfordshire, United Kingdom
}

\begin{abstract}
This paper aims to provide a first evaluation of the University of Bedfordshire Business School's innovative attempt to develop a new suite of Masters Programmes that delivers in terms of academic rigor and employability requirements while providing a rich student learning experience. The new delivery is based on a block delivery model that rationalises the previous offerings by providing a smaller range of standardized large units which are more tightly integrated to each other and are part of courses with particular characteristics such as a four-tier induction system (with inductions being progressively more employabilityfocused as students' progress from one unit to the next) and the final capstone unit where students have a choice between a traditional dissertation and an experiential final project. That common architecture is coupled with a flipped classroom delivery style, utilization of blended learning and rich peer-to-peer learning opportunities with multiple entry points providing additional students into the cohorts for each unit. Preliminary data is provided here as an early evaluation of the approach's effectiveness and efficiency in terms of the delivery experience, the assessment strategies, the levels of student engagement and performance, as well as the experience of staff and students.
\end{abstract}

Keywords: Block Delivery; Flipped Classroom; Blended Learning; Employability; Student Experience 


\section{Research Context}

The University of Bedfordshire Business School (UBBS) has been offering a range of Masters programmes since early 2000s. The postgraduate portfolio has evolved in recent years to accommodate recent developments: the choice of adopting a practice-based curriculum in UBBS, the dramatic changes in market demands, especially in the international student recruitment, more recently the focus on employability (HEA, 2013) and the introduction of TEF. In addition, UKVI challenges and changes in staffing composition have motivated a rationalisation and redesign of the Masters provision to enable building on established strengths whilst providing the School with a differential advantage.

In order to address competition and expectation issues within such a dynamic market, UBBS, led by the new faculty management team, has recently developed a new and innovative suite of MSc programmes with a focus on gaining further professional, statutory and regulatory body (PSRB) accreditations. The suite of programmes is based on a block delivery model that aims to rationalise the offerings by coalescing around six entry points per year and a standardised size of units (30 credits). This replaces the 11 entry points the school was previously running with a plethora of units of various credit sizes and repeated deliveries due to multiple entry points. The reduction in the overall number of units (from over 700 to around 50), a greater level of unit sharing across courses and the implemented block delivery model has enabled Heads of Department to efficiently manage staff time within the workload planning model. The overall design offers the following structural and pedagogical advantages over the previous delivery pattern:

- No pre-requisites; students do the unit that is running for their course when they join.

- Intensive induction week specifically aimed at preparing students for the learning experience rather than being solely articulated as an introduction to the institution and course. That includes the international students who due to visa challenges, often arrive late. Within the block delivery structure, late arriving students are accommodated in a 'step up to masters' course and then wait to join the full course at the next intake ensuring they do not miss any of the teaching for their course.

- Intensive, flexible classroom delivery in six-week blocks utilising blended learning; currently full-time with the potential for expanding into part-time, single unit or other patterns of study in order to fit with individual and/or employer requirements

- Inter-block period utilised to structure the four tier induction process and provide an opportunity to step back and think about course level learning outcomes, personal goals etc. 
- Rich peer to peer learning opportunities as multiple entry points provide additional cohort numbers to each unit.

- Scope for greater variety in terms of speakers, live projects, field trips as staff are not trying to coordinate everything in a traditional timetable often comprising of a 2-hour window once a week.

- No options until the final capstone when they have a choice of traditional dissertation or experiential route

- Personal development woven through the course as professional practice, and live project opportunities integrated into the curriculum (and particularly the final capstone)

The stakeholders were involved early on with the development of these new masters programmes. The faculty steered towards an integrated holistic change of the offering to conform with the philosophy outlined above. Professors of practice were involved in the practice/employability aspects of the curriculum, while the students via committees and focus groups were consulted in the development of interesting and relevant assessments.

Within the block delivery structure, students study 1 unit at a time and focus on only one assessment at a time. This concentrated focus has enabled students to explore topics in greater depth developing a level of criticality appropriate for level 7 education. Flipped classroom, practice-based and action-learning setups have been developed to assess students' learning and wherever possible the assessments are rooted in authentic and practical workplace scenarios to enable experiential learning. Particular emphasis has been put on the masters 'capstone experience' assessments allowing for greater integration and synthesis of learning.

The PG Suite of Programmes, at the time of writing, have recruited their first four intakes of the current academic year (2017/18). The block teaching delivery of the new programmes is in process. Thus a preliminary effort to evaluate these new programmes and examine their impact on pedagogic areas of importance such as the delivery and assessment strategies, the student engagement and performance, the experience of staff and students, as well as the courses' overall effectiveness has been undertaken. The business school has committed a group of academic staff to conduct a two-year longitudinal research with students and the teaching teams of the PG programmes. This paper reports the outcomes of the initial unit surveys and course learning experience surveys for the first 3 blocks. 


\section{Literature Review}

The 'flipped classroom' or 'blended learning' technique in pedagogic teaching has had a resurgence in recent years due to advances in technology, in particular mobile technologies, and institutions seeking to respond to student engagement, retention and progression challenges (Kurtz et al., 2014). It provides a mechanism for engaging students in their learning in a different way to more traditional models of teaching content in class. Technology innovation has facilitated a number of innovative pedagogies in higher education. Blended learning for example has had a strong impact in both practice (Unger et al., 2013) and Higher Education (Erdem \& Kibar, 2014; Lou et al., 2012; Wu et a., 2010) and is particularly suited to university courses where lecture content can be made available online and class time can then be prioritised for active student engagement (Boyinbode et al., 2013; McCarthy, 2010; Stacey \& Gerbic, 2007). The blended learning model is based on social constructivism, a student-centred learning theory that stresses the need for collaboration among learners and practitioners.

As Jensen et al. (2015) point out, only limited studies on the flipped learning model exist. The authors conducted a study into the effectiveness of this model using a quasiexperimental design comparing an active non-flipped classroom with an active flippedclassroom and found no difference in the level of learning gains and also equivalent satisfaction with the course. They concluded that an active learning style of instruction is more likely to result in higher learning gains rather than the order in which the instructor participated in the learning process. In line with extant studies, the School's block teaching embedding flipped classroom and blended learning are seen to support active learning and enhance students' learning experience and are fundamental to achieving the personal and professional development aspirations of the newly developed courses.

\section{Research Methodology}

After a preliminary literature review, a mixed method approach has been adopted for the data collection; student performance data and utilising the standard. University unit survey process supplemented with the Course Experience Questionnaire (CEQ), a well-established research tool around learning gains and the student experience. Furthermore, the CEQ also includes student learning preference and teaching orientation questions with a view to develop an insight into how learning preference orientations impact on students perceptions of satisfactions.. The outcomes from these sets of data will be triangulated to validate the final results and these will be further tested and explored via focus groups with students.

A longitudinal research design will be used to collect data. All three sets of data will be triangulated within a mixed methods research paradigm thus adopting a pragmatic perspective in the data collection and analysis. The data collected will be analysed systematically to draw conclusions, e.g. by comparing and contrasting between different 
intakes of the same course, and between different courses of the same time period. The aim will be that the outcomes from each of the intakes will be used to improve the teaching and delivery for subsequent intakes so that through this iterative process, these new Masters' programmes will be progressively improved and their quality enhanced.

While the unit survey is conducted at the end of every unit, the CEQ survey is repeated at every three blocks' interval. Thus, responding students on the CEQ will be at different stages in their learning journey. Some of the students may have completed one unit, some two and yet some more than two, depending on when they enrolled. This approach will allow the project team to understand students' perceptions regarding the teaching quality of the block-teaching diachronically; and at the same time to compare if there are differences among the perceptions of responding students across the whole learning journey.

The CEQ survey data will be analysed using SPSS with factor analysis used to identify the key factors that affect students' perceptions about the quality of the block-teaching. ANOVA will also be used to compare whether students at different stages or with different demographic characteristics have different perceptions.

Qualitative semi-structured interviews will be conducted to understand how and why students' perceptions are formulated and changing. This will allow the project team to develop an in-depth understanding of students' perceptions with regards to the quality of block-teaching, which will complement the finding from the questionnaire survey. NVIVO will be used to analyse the interviews.

In addition, focus groups with staff post-delivery of a unit will be conducted to evaluate the staff experience of teaching in the block delivery structure. This will be further supplemented with a staff experience questionnaire and interviews during the phase 2 of the project.

This paper presents the following information: A) The overall results of the unit surveys for the first two blocks of all MSc programmes as compared to those of the previous year (2015/16); B) The results of the first CEQ survey of the first three intakes of the year; C) The qualitative feedback from both unit survey and CEQ survey; and D) The results of the staff focus group that followed the delivery of the first three blocks. 


\section{Findings}

\subsubsection{The outcomes of the unit survey}

Table 1 encapsulates the overall assessment performance for the first two blocks of all PG programmes vis-à-vis the results for the previous year's cohort: (At the time of writing, the assessment boards had not taken place for block 3) The performance data for the previous year included main and resit results whereas the blocks data is based purely on the first sit assessment results.

Table 1 The overall performance of the first two blocks of the PG programmes compared to the previous year

\begin{tabular}{|c|c|c|c|}
\hline & $2015 / 16$ & Block 1 first sit & Block 2 first sit \\
\hline Pass Rate & $92 \%$ & $90 \%$ & $86 \%$ \\
\hline AB rate & $32 \%$ & $44 \%$ & $48 \%$ \\
\hline \#Academic Misconduct & 140 & 4 & 1 \\
\hline
\end{tabular}

As indicated, $\mathrm{AB}$ rate was significantly improved; this is not due to a lowering of assessment standards as externals have commented that, in many cases, the assessments are actually more challenging. The number of academic misconduct cases has fallen dramatically. Possible explanations for this are the more structured management of late arriving student who no longer need to meet an imminent deadline having missed a significant amount of the teaching and the opportunity within block delivery for better relationships to form between staff and students which is highly motivational for both sides. Furthermore,; focussing on one assessment at a time helps the students produce higher quality work and assessments are more closely tied in with the learning experience.

Overall the first block delivery was successful. Across 10 different units of delivery across the whole portfolio the unit surveys showed very high levels of satisfaction ranging from $80 \%$ to $100 \%$. Some of the highest performing courses are the ones with the smaller cohorts (II/V/VI) however there is one exception (III) which had 17 students and yet scored very high in satisfaction. Conversely some of the comparatively lower satisfaction courses (I/X) also had smaller cohort sizes therefore satisfaction was not apparently coupled to cohort size. The overall student results were satisfactory in terms of good grades.

The free text qualitative comments were quite uniform across all units and table 2 summarises the main themes emerging, 
Table 2 Comments from the unit surveys of the first intake of the PG programmes

\begin{tabular}{|c|c|c|c|c|}
\hline $\begin{array}{c}\text { Title of the } \\
\text { Unit }\end{array}$ & $\begin{array}{c}\text { No. of } \\
\text { positive } \\
\text { comments }\end{array}$ & Examples of good practice & $\begin{array}{c}\text { No. of } \\
\text { negative } \\
\text { comments }\end{array}$ & $\begin{array}{l}\text { Examples of areas for } \\
\text { improvement }\end{array}$ \\
\hline $\begin{array}{l}\text { I. Accounting } \\
\text { and Finance }\end{array}$ & 2 & $\begin{array}{l}\text { Learning and } \\
\text { understanding new } \\
\text { things about finance } \\
\text { and accounting }\end{array}$ & 2 & $\begin{array}{l}\text { More practical } \\
\text { application is needed } \\
\text { in order to adopt more } \\
\text { what we learn }\end{array}$ \\
\hline $\begin{array}{l}\text { II. Digital } \\
\text { Analytics }\end{array}$ & 3 & $\begin{array}{l}\text { Interesting topic } \\
\text { Enthusiastic tutor }\end{array}$ & 2 & $\begin{array}{l}\text { Getting used to block } \\
\text { teaching }\end{array}$ \\
\hline $\begin{array}{l}\text { III. } \\
\text { Employment } \\
\text { Law }\end{array}$ & 8 & Good helpful tutor & 4 & $\begin{array}{l}\text { Assessments set to } \\
\text { test time management } \\
\text { rather than intellectual } \\
\text { ability }\end{array}$ \\
\hline $\begin{array}{l}\text { IV. Financial } \\
\text { Market }\end{array}$ & 11 & $\begin{array}{l}\text { Practical, practice of } \\
\text { theory } \\
\text { Allows for autonomous } \\
\text { learning } \\
\text { Deep and better } \\
\text { understanding }\end{array}$ & 6 & $\begin{array}{l}\text { Not enough guidance } \\
\text { for assessments }\end{array}$ \\
\hline $\begin{array}{l}\text { V. Global } \\
\text { Logistics and } \\
\text { Supply Chain } \\
\text { Management }\end{array}$ & 7 & $\begin{array}{l}\text { Helpful tutor } \\
\text { Good interactive } \\
\text { sessions and extensive } \\
\text { guided learning }\end{array}$ & 5 & $\begin{array}{l}\text { Too intense } \\
\text { Too theoretical } \\
\text { not enough practice }\end{array}$ \\
\hline $\begin{array}{l}\text { VI. } \\
\text { Intellectual } \\
\text { Property }\end{array}$ & 4 & $\begin{array}{l}\text { Good starting point for } \\
\text { LLM } \\
\text { Discussion forum } \\
\text { interactive tutor }\end{array}$ & 4 & $\begin{array}{l}\text { Room is freezing }(\mathrm{x} 3) \\
\text { Block delivery system } \\
\text { takes time to get used } \\
\text { to }\end{array}$ \\
\hline $\begin{array}{l}\text { VII. } \\
\text { Intercultural } \\
\text { Business } \\
\text { Competencies }\end{array}$ & 26 & $\begin{array}{l}\text { Good teaching } \\
\text { Impressive delivery } \\
\text { Interactive }\end{array}$ & 21 & $\begin{array}{l}\text { Too much information } \\
\text { Too little time } \\
\text { More advise for } \\
\text { assessment }\end{array}$ \\
\hline $\begin{array}{l}\text { VIII. Leading } \\
\text { and Managing } \\
\text { Organizational } \\
\text { Resources }\end{array}$ & 17 & $\begin{array}{l}\text { Clearer understanding; } \\
\text { critical thinking } \\
\text { friendly class } \\
\text { atmosphere }\end{array}$ & 19 & $\begin{array}{l}\text { More information } \\
\text { about assessments } \\
\text { Time scheduling }\end{array}$ \\
\hline
\end{tabular}




\begin{tabular}{|l|c|l|c|l|}
\hline $\begin{array}{l}\text { IX. Project } \\
\text { Management } \\
\text { practice }\end{array}$ & 7 & $\begin{array}{l}\text { Team work } \\
\text { good delivery }\end{array}$ & 6 & $\begin{array}{l}\text { Timetabling } \\
\text { Too fast }\end{array}$ \\
\hline $\begin{array}{l}\text { X. Tourism } \\
\text { policy and } \\
\text { Practice }\end{array}$ & 7 & $\begin{array}{l}\text { Motivation to critical } \\
\text { thinking } \\
\text { Educational Trips }\end{array}$ & 6 & $\begin{array}{l}\text { Can be more linked to } \\
\text { hospitality }\end{array}$ \\
\hline
\end{tabular}

\section{A) The results of the first CEQ survey}

The first CEQ survey shows that 94 out of the 175 respondents (54\%) commented on best aspects of the block delivery while 74 (42\%) commented on aspects of the block teaching that need improvement. Through thematic analysis the responses were grouped into eight categories: 1) Block deliver (course design); 2) Teachers expertise and teaching style; 3) Assessment and feedback; 4) Personal and professional development; 5) Supporting resources (learning materials, guided learning, communication, study environment); 6) Timetabling; 7) practicality and employability; and 8) Collaborative learning.

The analysis of data showed that personal and professional development, teachers' expertise and their teaching styles; and the design of block delivery itself were the top three best aspects of block delivery, each with comments from over $20 \%$ of respondents. The next two aspects that were commented fair number of respondents were collaborative learning (14\%) and supporting resources $(9 \%)$

On the other hand, the respondents also found aspects of the block teaching that need improvement, among which the top four aspects were assessment and feedback (26\%), supporting resources $(23 \%)$ teacher's expertise and teaching style $(20 \%)$, and practicality and employability (15\%). 


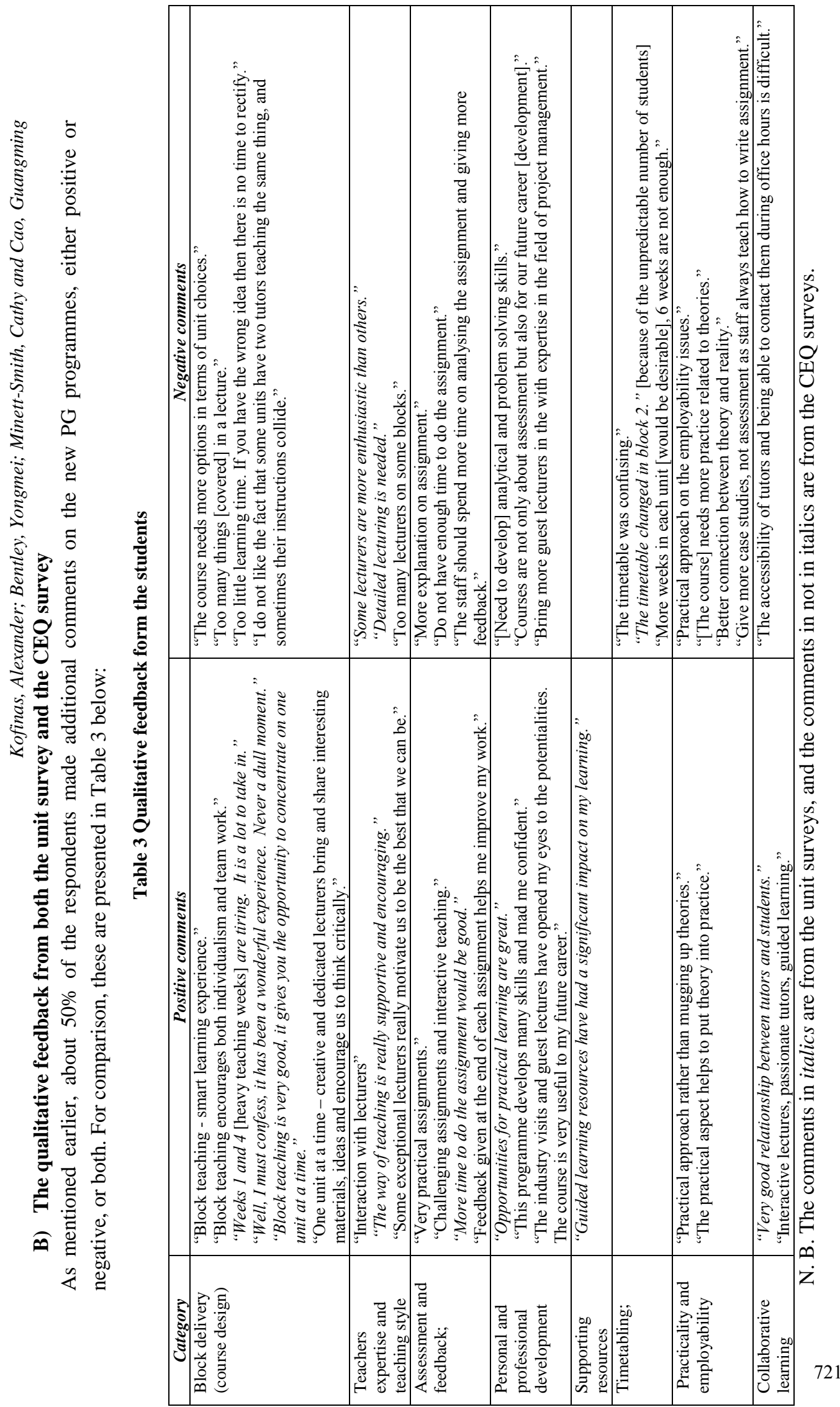


Despite the diversity of topics, tutors and deliveries, there is an unexpected consistency in comments received and Table 3 provide some typical examples. On the positive side: critical thinking, good understanding, good relationships with tutors and interesting deliveries, which are consistent with research on flipped classroom (Kurtz et al., 2014) or blended learning (Unger et al., 2013). On the side that needs improvements the comments were mostly about: a. the intensity of the blocks indicating that for students the delivery mode was indeed novel and quite challenging to adjust to; b. perceptions of timetabling issues; c. perceived lack of time to do assignments properly.

It is a bit like marmite - love it or hate it. Students clearly find that the block teaching delivery is intense but fun and the practical learning is really appreciated. The actual learning time for assessments is the same in block delivery as it was for the previous delivery but the perception of reduced time is very real to the students. The timetable is static for a block but will change as students move from block to block which is different to their prior experiences where they typically had a timetable for the year. Whilst all this is covered during induction some students fail to attend the full induction process. This is an aspect that the team will consider exploring in detail to examine the extent to which attendance at induction is an explanatory factor in student performance and engagement. However, it is clear that more effort needs to be invested in managing student expectations.

\section{C) Feedback from the staff focus group}

The staff focus group that followed the delivery of the first block uncovered revealed some interesting insights:

Table 4: Examples of staff feedback from focus group

\begin{tabular}{|c|c|}
\hline Positive feedback & Negative feedback \\
\hline $\begin{array}{l}\text { "Student engagement has } \\
\text { improved." } \\
\text { "Much better interaction with } \\
\text { students, we get to know them } \\
\text { better and form good } \\
\text { relationships." } \\
\text { "Bring students together into } \\
\text { larger cohorts has enriched the } \\
\text { experience for everyone." } \\
\text { "Skills gaps (such as numeracy) } \\
\text { surface more quickly and can be } \\
\text { addressed." }\end{array}$ & $\begin{array}{l}\text { "Students who miss induction struggle to catch up." } \\
\text { "I worry that the new students are getting left } \\
\text { behind." } \\
\text { "Skills development (e.g. critical writing) needs a } \\
\text { coordinated course level approach." } \\
\text { "Frictions amongst students can escalate quickly } \\
\text { when there are less gaps in the learning experience } \\
\text { for them to cool down." } \\
\text { "[It was] challenging and demanding to deliver the } \\
\text { first time." } \\
\text { "Tough to teach a block if you have UG teaching at }\end{array}$ \\
\hline
\end{tabular}




\begin{tabular}{|c|c|}
\hline $\begin{array}{l}\text { "Blended learning has resulted in } \\
\text { a greater variety of learning } \\
\text { experience, and has also enriched } \\
\text { the staff experience." } \\
\text { "I was reluctant to blocks but the } \\
\text { change has made me a better } \\
\text { teacher." }\end{array}$ & $\begin{array}{l}\text { the same time." } \\
\text { "Team teaching is a challenge.It's nightmare when } \\
\text { someone doesn't pull their weight -the Head of } \\
\text { Department needs to step in." } \\
\text { "Cross departmental teaching teams are difficult to } \\
\text { coordinate." } \\
\text { "Keeping complex team teaching on the road is } \\
\text { really hard." }\end{array}$ \\
\hline
\end{tabular}

The staff have identified the pivotal role that the induction process plays in ensuring that students 'hit the ground running' and succedd in the block delivery model. This was most noticeable in staff perceiving that students engaged and performed better in the second half of the unit. As successive blocks have recruited the faculty is now in the position of having students in their first, second, third and fourth block of study across all units and the use of peer learning could be a focus of future activity in response to this challenge,

The staff acknowledge that the new block delivery structure has dramatically improved the complexity of the PG provision as evidenced by the fact that they would not choose to return to the old system. The learning experience has also improved for both staff and students with greater variety and scope to include innovative employability aspects in the provision with guest speakers and visits etc, However, there are still challenges to overcome associated with transparently managing the fluctuating cohorts of students and administrative systems need to flex accordingly to support this. The main challenges in delivery are linked with team teaching and the merging of block teaching at PG level with more traditional delivery patterns at UG. Staff development was embedded in the implementation plan for the new delivery as both a faculty wide development and with core teams of staff as they prepare for each block of delivery. More focussed staff development is now needed in the area of team teaching in particular and consider the organisational structures that support the activity.

Future staff focus groups will explore the issues in more depth. with a focus on how staff manage the dynamic of having mixed cohorts of students in their $1^{\text {st }}, 2^{\text {nd }} 3^{\text {rd }}$ or $4^{\text {th }}$ block. At the time of writing, staff who taught the first block are preparing to teach the unit again; this provides a valuable opportunity to evaluate how they are adapting their practice based on their experience in block teaching delivery.

\section{Conclusions}

This is a work in progress and the current paper represents only the first chapter on a longitudinal study. The team believes that block delivery is different from more traditional 
postgraduate deliveries and that the data so far indicate that the experience is of a high quality and translates to high levels of engagement and performance for staff and students. Student performance and satisfaction have improved even though the external examiners think assessments have got more challenging. The preliminary findings also indicate that there are certain things worth exploring such as students' perceptions of the assessment, the levels of engagement they should exhibit to perform well, developing the four tier induction process and strategic development of peer learning strategies.

The course team will conduct more detailed statistical analysis of the course experience questionnaires with a focus on learning preferences; and detailed staff evaluation with a focus on 'teacher' preferences. Then we will aim to further improve the delivery model,

The course team is confident that once the novelty of the block pedagogy wears off, the peer-to-peer activity coupled with the employability focused inductions will enhance our students' performance and learning experience. These early findings will be augmented by further periodic unit surveys and CEQ surveys on student course experience and learning, as well as student exit focus groups examining the whole learning journey.

\section{References}

Boyinbode, O., Ng'ambi, D., \& Bagula, A. (2013). An interactive mobile lecturing model: Enhancing student engagement with face-to-face sessions. International Journal of Mobile and Blended Learning, 5(2), 1-21.

Erdem, M., \& Kibar, P. N. (2014). Students' opinions on facebook supported blended learning environment. Turkish Online Journal of Educational Technology, 13(1), 199206.

HEA. (2013). Learning Journeys: Student experience in further and higher education in Scotland. Edinburgh: Higher Education Academy.

Jensen, J. L., Kummer, T. A., \& Godoy, P. D. d. M. (2015). Improvements from a flipped classroom may simply be the fruits of active learning. CBE-Life Sciences Education, 14(1), ar5.

Kurtz, G., Tsimerman, A., \& Steiner-Lavi, O. (2014). The Flipped-Classroom Approach: The Answer to Future Learning? European Journal of Open, Distance and E-Learning, 17(2), 172-182.

Lou, S. J., Chen, N. C., Tsai, H. Y., Kuo-Hung, T., \& Shih, R. C. (2012). Using blended creative teaching: Improving a teacher education course on designing materials for young children. Australasian Journal of Educational Technology, 28(5), 776-792.

McCarthy, J. (2010). Blended learning environments: Using social networking sites to enhance the first year experience. Australasian Journal of Educational Technology, 26(6), 729-740.

Stacey, E., \& Gerbic, P. (2007). Teaching for blended learning - Research Perspectives from on-campus and distance students. Educational Information Technology, 12. 
Unger, K., Schwartz, D., \& Foucher, J. (2013). Increasing Employee Productivity through Gamification and Blended Learning. Paper presented at the World Conference on ELearning in Corporate, Government, Healthcare, and Higher Education.

Wu, J.-H., Tennyson, R. D., \& Hsia, T.-L. (2010). A study of student satisfaction in a blended e-learning system environment. Computers \& Education, 55(1), 155-164. 